University of Wollongong

Research Online

Faculty of Business - Papers (Archive)

Faculty of Business and Law

$1-1-2015$

(Dis)Engaging with Sustainability: Evidence from an Australian Business Faculty

Maria Cadiz Dyball

Macquarie University

Andy Wang

Australian Catholic University, andywang@uow.edu.au

Sue Wright

Macquarie University

Follow this and additional works at: https://ro.uow.edu.au/buspapers

Part of the Business Commons

Research Online is the open access institutional repository for the University of Wollongong. For further information contact the UOW Library: research-pubs@uow.edu.au 


\title{
(Dis)Engaging with Sustainability: Evidence from an Australian Business Faculty
}

\begin{abstract}
Purpose - The purpose of this paper is to explore how the lack of staff engagement with a university's strategy on sustainability could be an enabling lever for organisational change. It examines the attitudes and views of employees of a business faculty at an Australian metropolitan university as it attempts to adopt a holistic approach to sustainability. Design/methodology/approach - The paper opted for a case study using data from an on-line survey, semi-directed interviews with key management personnel and archival material. Responses were analysed using Piderit's (2000) notion of ambivalence. Findings - The paper provides empirical insights into why staff lacked engagement with the university's strategy on sustainability. It suggests that staff were ambivalent, displaying dissonance in their personal beliefs on sustainability, the university's strategy and the extent of their intentions to support the university. Staff were willing to offer ideas on how the university could, in the future, change towards sustainability. These ideas allow the possibility for the university to learn to adjust the scope of the implementation of its sustainability strategy. Research limitations/implications - The research results may lack generalisability. Therefore, researchers are encouraged to further examine staff attitudes on sustainability in higher education using Piderit's notion of ambivalence. In-depth interviews and focus group discussions could allow a better understanding of harmony and dissonance in cognition of and intention for university sustainability strategies and initiatives by academic, professional and sessional staff. Practical implications - The paper includes implications for staff engagement with sustainability in higher education. Originality/value - This paper fulfils an identified need to study how staff engagement with sustainability in higher education can be enabled for organisational learning.
\end{abstract}

\section{Keywords}

faculty, evidence, (dis)engaging, sustainability:, business, australian

Disciplines

Business

\section{Publication Details}

Dyball, M. Cadiz., Wang, A. F. \& Wright, S. (2015). (Dis)Engaging with Sustainability: Evidence from an Australian Business Faculty. Accounting, Auditing \& Accountability Journal, 28 (1), 69-101. 


\title{
(Dis)Engaging with Sustainability: Evidence from an Australian Business Faculty
}

\begin{abstract}
Purpose - The paper explores how the lack of staff engagement with a university's strategy on sustainability could be an enabling lever for organisational change. It examines the attitudes and views of employees of a business faculty at an Australian metropolitan university as it attempts to adopt a holistic approach to sustainability.
\end{abstract}

Design/methodology/approach - The paper opted for a case study using data from an on-line survey, semi-directed interviews with key management personnel and archival material. Responses were analysed using Piderit's (2000) notion of ambivalence.

Findings - The paper provides empirical insights into why staff lacked engagement with the university's strategy on sustainability. It suggests that staff were ambivalent, displaying dissonance in their personal beliefs on sustainability, the university's strategy and the extent of their intentions to support the university. Staff were willing to offer ideas on how the university could, in the future, change toward sustainability. These ideas allow the possibility for the university to learn to adjust the scope of the implementation of its sustainability strategy.

Research limitations/implications - The research results may lack generalisability. Therefore, researchers are encouraged to further examine staff attitudes on sustainability in higher education using Piderit's notion of ambivalence. In-depth interviews and focus group discussions could allow a better understanding of harmony and dissonance in cognition of and intention for university sustainability strategies and initiatives by academic, professional and sessional staff.

Practical implications - The paper includes implications for staff engagement with sustainability in higher education.

Originality/value - This paper fulfils an identified need to study how staff engagement with sustainability in higher education can be enabled for organisational learning.

Keywords Staff engagement, Sustainability, University business faculty, Organisational change

Article Type Research paper

\section{Introduction}

Universities operate in a world of change (Adams, 1998; Nagy and Robb, 2008; Parker, 2002) and are at the forefront in the production of the most advanced knowledge (Albrecht et al., 2007; Levin and Greenwood, 2001; Senge, 2000). Universities have unique academic freedom, the critical mass and a diversity of skills to develop ideas and to comment on society and its challenges (Cortese, 2003, p.17). However, they can be deeply conservative, frustrating learning and change from within (Halsey, 1979; Levin and Greenwood, 2001). Highly autonomous university sub-systems like faculties and departments can thwart systemic changes across the institution (Dearlove, 1998; Weick, 
1976). Characterised as loosely coupled, faculties and departments in universities are connected to each other and autonomous at the same time (Godemann et al., 2014). With this arrangement is the potential for opposition to new ideas and strategies (Cooper and Muth, 1993; Elton, 1981; Orton and Weick, 1990; also see Godemann et al., 2014). Whilst resistance is commonly cast in a negative light and as an enemy of change (Schein, 1988), there are advantages to resistance which can be utilised by an organisation to assist institutional learning and change (Ford et al., 2008; Knowles and Linn, 2004; Waddell and Sohal, 1998). After all it is a fallacy to assume that all changes are 'good'.

Resistance to change is not the fundamental problem to be solved. Rather, any resistance is usually a symptom of more basic problems underlying the particular situation. Resistance can serve as a warning signal ... (Judson, 1966, p.69).

The opposite response of employee apathy is particularly more dangerous when there is a need for change (Litterer, 1973). Where resistance is evident from employees, a closer examination of the problems that exist is required.

A movement to promote sustainability in higher education was launched in 1990 with the Talloires Declaration ${ }^{1}$ (Clugston and Calder, 1999). Yet a decade later, education for a sustainable world was not a high priority (Gudz, 2004; Mcintosh et al., 2001). Sustainability in higher education was given a renewed emphasis in 2002 at the World Summit on Sustainable Development (United Nations, 2002). Sustainability is a complex concept and poses challenges for universities to own (Moore et al., 2005). It challenges the way they act, the way they teach and even the way they think. It demands that universities have the capacity to learn by either adapting or modifying their systems of beliefs, ideas and actions (Glynn et al., 1994; Miner and Mezias, 1996).

The paper examines the attitudes and views of employees of a business faculty in an Australian metropolitan university at which the authors were working or studying as that 
institution attempted to adopt a holistic approach to sustainability. The temporal focus of the study is during the first two years of the strategy's implementation. Whilst there is evidence of resistance, this study shows that the lack of staff engagement with a university's strategy on sustainability could be an enabling lever for organisational change. Staff resistance which stems from discordant cognitive and intentional responses to organisational change could help draw attention to aspects of change which may be not planned or implemented well enough. It could provide feedback to top management to adjust the scope of the implementation of the change, thus enabling organisational learning. Staff resistance could be an opportunity for the organisation to modify its priorities and direction; to clarify staff's roles and skills; to adapt its accountability mechanisms and increase staff involvement (Kezar and Eckel, 2002). Whilst staff from the university investigated in this study generally thought that sustainability was a worthwhile strategy to pursue, survey and interview data also point to a state of ambivalence to its systemic adoption. Despite their cognitive and intentional ambivalence, employees voice short and longer term ideas to embed sustainability in the university's belief system, plans and actions. It is our view that top management would be wise to heed staff's ambivalence and recommendations to shape organisational change for sustainability at the university.

The remainder of the paper is developed in four sections with Section 2 dedicated to a review of the relevant literatures. Sections 3 and 4 present the research method and the study's findings, respectively. The implications of the findings and conclusions are discussed in Section 5.

\section{Literature Review}

\subsection{Universities, staff and academic work}

The environment in which Australian universities operate is highly dynamic with universities competing with other providers of tertiary qualifications to generate revenues 
(Nagy and Robb, 2008) as a response to reduced government funding in real terms (Parker, 2002). Universities are managing themselves through formal strategic processes, revenue generation coupled with cost efficiency initiatives and performance based management techniques (Guthrie and Neumann, 2007; Parker, 2005). Business schools, in particular, have become adept at commodifying education to successfully generate revenues for universities (Parker and Guthrie, 2010).

University staff include academic, sessional and professional staff. Academics are involved in research and teaching, although some academics participate in the administration of their collective affairs. Sessional staff typically assume teaching roles but are not permanently employed or tenured unlike most academic staff (Bassett and Marshall, 1998). They are commonly employed on an ad hoc basis, paid by the hour and do not have access to paid leave and research funding. Sessionals also generally occupy the lower rungs in the academic hierarchy, usually at lecturer and associate lecturer levels in Australian universities. Bassett and Marshall (1998) found in their review of the literature that sessionals tend to be denied full participation in academia and their employment is characterised by uncertainty and insecurity. Professional staff or administrators are a group of staff who are not employed as academics and whose primary function is management rather than the provision of academic services (Conway, 2000). They are located predominantly in faculties where the core activities of teaching and research are conducted. The differences in the nature of work and employment of university staff are manifest in how they are managed. Sessional and professional staff are administered through bureaucratic structures, regulated procedures and hierarchical organisation (Dearlove, 1998). Academics, on the other hand, generally expect to enjoy individual autonomy as they assert their right to academic freedom. 
Australian academics, like their confreres elsewhere, derive a level of intrinsic rewards from their work and value their academic freedom to create and disseminate knowledge (Adams, 1998). Business academics are no exception because they also want to make academic contributions and not be relegated to the role of revenue generators (Ryan et al., 2008). Universities embody clusters of academics that are intellectually strong, technically trained and individually creative (Becher and Kogan, 1992). These clusters are historically organised based on disciplines, departments and faculties and are 'loosely coupled' to each other. Crucially, employee autonomy and freedom are bound to deny just about any organisation its importance and legitimacy (Dearlove, 1998, p.71). As Dearlove (1998) elaborated, in the case of universities, a typical situation is that many important decisions about teaching and research are made by individual academics, who resent institutional intrusion into what they see as "their" time and work. This situation also helps explain why from within, universities can be deeply conservative when it comes to organisational change (Halsey, 1979; Levin and Greenwood, 2001). Departments and faculties are institutionalised locales for multiple points of opposition to new ideas and strategies (Cooper and Muth, 1993; Elton, 1981). The following quote from Gudz (2004, p.164) of an academic reflecting on the implementation of a sustainable development policy at the University of British Columbia captures the essence of traditional academic opposition to enforced changes from the 'top':

It's like moving a super-tanker. (University) Presidents don't get to come in and actually say we're going to teach in new ways and have it happen! ... Faculty members have a lot of freedom to teach what they want, to do research about what they want. Department heads don't actually get to tell us what to do.

Academic autonomy as a characteristic of academic work can help explain the slow and sporadic response to incorporate sustainability in higher education (Gudz, 2004; McIntosh et al., 2001). Equally pertinent is the range of experiences of sustainability by academics 
which seems to be inconsistent with the accepted rhetoric of experts in the area of sustainable development (Reid and Petocz, 2006). In their study of academics from an Australian university, Reid and Petocz (2006) observed a low degree of awareness of issues relating to sustainability and little integration into teaching programs. Notably, this observation was made more than a decade after the 1990 Talloires Declaration (Clugston and Calder, 1999) and after the renewed call in 2002 at the World Summit on Sustainable Development (United Nations, 2002) to incorporate sustainability in higher education. The language of sustainability was simply not a part of the academics' vocabulary (Reid and Petocz, 2006, p.120).

So far, we have described business schools as adept at commodifying education to successfully generate revenues for Australian universities (Parker and Guthrie, 2010). We juxtaposed this development with a discussion of how academic work is typically organised, drawing out how academic autonomy and freedom can be bulwarks of resistance against strategic changes imposed from the 'top'. We also described university staff, highlighting differences in employment and management of academic, sessional and professional staff. We now explore the concept of resistance and how it can be utilised by an organisation to assist institutional learning and change (Ford et al., 2008; Knowles and Linn, 2004; Waddell and Sohal, 1998).

\subsection{Employee resistance and organisational change and learning}

'Employee resistance' refers to all oppositional or negative reactions by employees to change proposals that alter the status quo (Piderit, 2000; Zaltman and Duncan, 1977). It could introduce delays, costs and instabilities into the process of strategic change in organisations (Ansoff, 1988). Indeed a prevailing view of resistance to change proposes that it is an irrational and dysfunctional reaction located 'over there' in change recipients (Ford et al., 2008). ${ }^{2}$ This perspective is decidedly one sided and in favour of change agents (Dent and 
Goldberg, 1999; King and Anderson, 1995). It is presumed that "change agents are doing the proper things while change recipients throw up unreasonable obstacles or barriers" to the change (Ford et al., 2008, p.362). Within this view, resistance cannot be a result of rational and coherent consideration by change recipients (Jermier et al., 1994; Knowles and Linn, 2004; Wegener et al., 2004; Jermier et al., 1994). However, such a characterisation of resistance overlooks its potential contributions to increasing the likelihood of successful change (Knowles and Linn, 2004: Waddell and Sohal, 1998). As Ford and colleagues (2008, p.363) pointed out, resistance could help "build awareness and momentum for change and eliminate unnecessary, impractical or counterproductive elements in the design or conduct of the change process".

But why do employees defensively respond to change? Piderit (2000) synthesizing studies by scholars such as Modigliani and Rochat (1995) and Ashford and colleagues (1998), stated that resistance might be due to employees trying to get top management to pay attention to issues that they believe must be addressed or by individuals' desires to act in accordance with their ethical principles. The different emphases by these scholars on beliefs and desires to act led Piderit (2000) to propose that resistance could have three dimensions: cognitive, emotional and intentional. The cognitive dimension refers to an individual's beliefs about the attitude object. Beliefs express positive or negative evaluation of greater or lesser extremity and occasionally are exactly neutral in their evaluative content (Eagly and Chaiken, 1998, p.271). Thus, employees' responses to organisational change along the cognitive dimension might be anywhere in a range from strong positive beliefs to strong negative beliefs. The emotional dimension relates to an individual's feelings in response to the attitude object. Employees could demonstrate strong positive emotions such as excitement to strong negative emotions like anger. In this study, however, we do not explore the dimension of emotion. The intentional dimension represents a person's plan or resolution 
to take some action (Bagozzi, 1992). Persons could have strong positive intentions to support the change to negative intentions to oppose it. Notably individuals could have different reactions along the different dimensions, which suggest that they could have ambivalent attitudes. Ambivalence could occur, for example, where alternative perspectives are strongly manifested in two dimensions. An individual might have a strong positive belief about the proposed change but have a negative intention to not support it. "Accordingly, it is possible for change recipients to be internally positive toward a change whilst simultaneously taking actions or delivering communications that change agents call resistance" (Ford et al., 2008, p. 371). Ambivalence could also occur along one dimension where for instance, an employee believes a proposed change is both necessary for the organisation's survival in the industry but not yet sufficiently planned.

Hence, employees' resistance to change is not necessarily an unwarranted and detrimental response. As Knowles and Linn (2004) proposed, resistance can be valuable for the existence, engagement and strength of a change. It has the potential to be an enabling agent for change management. Waddell and Sohal (1998, p.545) identified at least four reasons why employee resistance could be advantageous for organisations proposing change. First, resistance could act as a factor that balances pressure from the external and internal environments to change against the need for constancy and stability. The latter allows organisations a level of predictability and control of their processes (also see Brehm, 1966). Second, resistance could help draw attention to aspects of change which may be inappropriate, not planned well enough, or perhaps plain wrong (also see Brunsson, 1986). Third, resistance could bring about an influx of energy. The opposite responses of apathy and mere acquiescence are dangerous when there is a need for growth and development (Litterer, 1973; also see Wegener et al., 2004). A degree of negative emotion, say dissatisfaction, could translate into enough motivation to do something about the proposed 
change. Lastly, resistance could encourage the search for alternative methods to resolve the conflicting views on the proposed change. It could be the catalyst for innovation (also see Amason, 1996).

Thus, there is the possibility of an energising link between employee resistance and organisational adaptation and learning. Of particular relevance to this study's focus on a university is Dearlove's reflection (1998) on how to effectively implement institutional changes in universities. He acknowledged employee resistance and encouraged "organised anarchy to throw up alternative perspectives on problems as well as possible solutions" (Dearlove, 1998, p.74). Such is the stance taken in this study despite the dominant view of resistance as a phenomenon whereby employees must be shown "the 'errors of their ways', by dealing with the misunderstandings, fears and apprehensions believed to underlie their resistance" (Ford et al., 2008, p. 370). Rather, both change agents and change recipients engage in sense making (Gioia et al., 1994). Change recipients, in particular, initially assess the likelihood of the change leading to personal and organisation benefits (Kim and Rousseau, 2006). As change unfolds, they also compare actual results to the original promises and projections (Tomlisson et al., 2004). For change agents, 'resistance' could be seen as feedback of change recipients' sense making to adjust the pace, scope or sequencing

of the implementation of the change (Amason, 1996). In this study, we obtained feedback from staff at a business faculty through an anonymous survey and interviews to get a sense of their views of the university's sustainability strategy and its early implementation. The discussion that follows examines literature on sustainability in higher education and 'barriers' to the introduction of sustainability in higher education.

\subsection{Sustainability and barriers to sustainability in higher education}

Sustainability is a complex concept and poses challenges for universities to own (Moore et al., 2005). In the last two decades or so higher education institutions have played 
a pivotal role in promoting and implementing a program called Education for Sustainability Development (ESD). The notion of ESD originated from the United Nations Educational Scientific and Cultural Organisation (UNESCO) in 1978. A further call for promoting education, public awareness and training in sustainable livelihoods was made at the United Nations Conference on Environment and Development in Rio de Janeiro in 1992 (Holdsworth et al., 2008). In 2002, UNESCO released a manifesto called the Decade of Education for Sustainable Development (DESD) (2005-2014) with the aim to integrate the principles, values and practices of sustainable development into education (UNESCO, 2002).

Interestingly, no formal definition of sustainable development was given in the DESD. However, it seems to adopt the most frequently cited definition in the Report of the World Commission on Environment, which stated that sustainable development is the development that "meets the needs of the present without compromising the ability of future generations to meet their own needs" (United Nations World Commission on Environment, 1987, p.8). This definition highlights the need to change the way we think, live, consume and work as current actions are leading to environmental degradation, poor quality of life and associated human suffering. Education, learning and capacity building were endorsed as a means to bring about change and engage people in creating a sustainable future. The DESD called to integrate sustainable development into education systems at all levels in order for education to be a key agent for change. It promoted education as the basis for sustainable human society and to strengthen international cooperation towards the development of innovative policies, programs and practices of education for sustainable development (UNESCO, 2002).

In response to community and international awareness of sustainability, a series of declarations were signed by over one thousand universities, including some from the 
Australian higher education sector, with a commitment to change towards sustainability (Tilbury et al., 2005). A wide range of sustainability initiatives were developed and implemented. However, most of these initiatives took the form of an add-on approach or a project-based program, such as waste recycling, water retention, tree planting, car-pooling, and energy reduction. Few universities appear to have adopted a holistic approach to sustainability (Tilbury et al., 2005). The university investigated in this paper had stated that it intended to adopt a holistic approach to sustainability.

The literature identified three main types of barriers to the integration of sustainability initiatives into higher education. The first barrier is the lack of a shared meaning of sustainability (Bekessy et al., 2007; Reid and Petocz, 2006; Tilbury et al., 2005; Velazquez et al., 2005). The ineffective dissemination of information on sustainability and training of members (Thomas, 2004; Tilbury et al., 2005; Velazquez et al., 2005; Evangelinos et al., 2009) have also hampered the growth and sharing of knowledge on sustainability initiatives among the various stakeholders of universities.

The second barrier is the lack of sufficient organisational resources to support sustainability initiatives. Financial constraints, for example, have posed a serious threat to the implementation of initiatives (Bekessy et al., 2007; Evangelinos et al., 2009; Sammalisto and Arvidsson, 2005; Thomas, 2004; Tilbury et al., 2005; Velazquez et al., 2005).

The third barrier is the lack of interest, commitment and participation by stakeholder groups (Evangelinos et al., 2009; Tilbury et al., 2005; Velazquez et al., 2005), more so with the dearth in rewards, incentives or recognition for individual contributions to sustainability (Ferrer-Balas et al., 2008; Tilbury et al., 2005). The third barrier potentially speaks to employee resistance and its three dimensions of cognition, emotion and intention, as proposed by Piderit (2000; also see Section 2.2). The lack of interest could reflect a negative 
belief in sustainability. The lack of commitment could reflect a negative emotion of apathy, whilst the lack of participation could suggest an intention not to support sustainability.

Nonetheless, there appears to be a continuing interest in sustainability in higher education with four identified driving forces, namely, (1) government regulation, as in the cases in Sweden and Japan (Evangelinos et al., 2009; Ferrer-Balas et al., 2008; Sammalisto and Arvidsson, 2005), (2) reputation management, viz, to improve image and create goodwill, as in the case of Swedish universities (Sammalisto and Arvidsson, 2005; also see Bebbington et al., 2008), (3) pressure from peer institutions (Ferrer-Balas et al., 2008), and (4) the availability of funding for sustainability (Evangelinos et al., 2009, Ferrer-Balas et al., 2008).

In examining the views and attitudes of employees to a sustainability strategy introduced by top management, the authors are mindful that employee resistance is a barrier to sustainability in higher education (Evangelinos et al., 2009; Tilbury et al., 2005; Velazquez et al., 2005; also see Piderit, 2000). We are also sensitive to its enabling potential to generate innovative ideas (Dearlove, 1998; Waddell and Sohal, 1998). The survey and interviews, which we describe in the next section solicited employees' views on sustainability at the university and also gathered ideas on how sustainability could be embedded in the university's belief system, plans and actions. The approach was to identify if there was resistance to the university's strategy on sustainability, analyse whether resistance was mainly due to ambivalence arising from inconsistencies along the dimensions of cognition and intention as explained by Piderit (2000), and draw ideas from staff as inputs to organisational learning.

\section{Research method}

\subsection{The University}


Three significant pieces of regulation had exerted pressure on the Australian university sector to address sustainability in the period immediately prior to this study, which was conducted in 2009. First, in 2005, the state government required high energy users (including the university studied in this paper) to produce Energy Savings Action Plans. The university prepared such a plan, outlining detailed uses and potential savings of energy. Second, the National Greenhouse and Energy Reporting Act 2007 was enacted by the Australian Government as a response to the Kyoto Protocol. This also required the university to report its energy production, usage and greenhouse gas emissions. Third, in 2008, a Carbon Pollution Reduction Scheme was proposed, which would require detailed record-keeping, reporting and independent assurance of carbon emissions.

The business faculty of the Australian metropolitan university studied in this paper and at which the authors were working or studying, is located at a park-like campus with a large area of natural space containing a number of threatened ecological vegetation communities. Sustainability was integrated into the university's strategy in 2007 in response to aforementioned regulations and legislative changes. A holistic approach was purported to be adopted to extend education for sustainability principles into all aspects of the university. The university was the first Australian university to set sustainability as its strategy. It set its sustainability vision to be "ecologically sound, socially just and economically viable in all of its activities".

This change was one of many in a period of significant upheaval to all parts of the university, starting with the arrival of a new Vice-Chancellor after a long period under the rule of the previous one. Far-reaching changes to curriculum were being developed during the period of study, a new university logo and vision were launched, and there were substantial changes to the university's organisational structure. One of the changes to its organisational structure saw the establishment of a Sustainability Office to coordinate a 
university-wide program of change. A Sustainability Working Group (SWG) was also set up from a wide range of functions from the university. The working group was responsible for providing suggestions on sustainability initiatives, programs, activities and communications, offering a focal point to support learning and teaching for sustainability across the campus, and facilitating networking among those engaged in sustainability. Sustainability action groups were also formed to look after the operational aspects of the university's sustainability strategy. Sustainability projects included water consumption, reduction of greenhouse gas emissions and recycling of water and paper. Moreover, detailed objectives, indicators and targets for short, medium and long term sustainability were developed. The university's students' services provider, for example, formed its own sustainability initiatives and incorporated them as part of a performance measurement system for its employees.

Up until the second half of 2009 when data for this study were obtained, sustainability initiatives had spread into most parts of the university's operations. A comprehensive waste audit was conducted, battery and mobile phone recycling stations were introduced at two locations on campus, personal paper recycling bins were installed in offices resulting in an increase of approximately $40 \%$ in paper recycling and approximately 25,000 kilos of electronic waste was collected on four e-waste disposal days. In addition, a Water Savings Action Plan and an Energy Saving Action Plan were developed and Green Energy worth $5 \%$ of total demand was purchased. A list of indicators and targets were drafted, and in early 2009, the university released its first sustainability report and targets were set for 2014.

\subsection{Data collection}

This study adopted a complementarity mixed-method design whereby qualitative and quantitative methods are used to measure overlapping but also different facets of a 
phenomenon (Greene et al., 1989). The study aims to provide an enriched and elaborate understanding of the phenomenon of business staff's resistance to the implementation of a sustainability strategy at an Australian university. Data were collected from archival materials, an anonymous on-line survey and semi-directed interviews with key management personnel in the university's Sustainability Office and business faculty. ${ }^{3}$ Archival materials included the university's sustainability strategy document, sustainability report for 2009 and minutes of meetings of the university SWG from 2008, the year of its inception to 2009, when the study was conducted. Survey questions were mainly drawn from prior literature. The survey questions were typically close-ended questions with a few open-ended ones to allow respondents to share their views and comments. There were 25 questions grouped into five sections: Section A asked for demographic information, Section B sought to identify their knowledge and views about sustainability and Section $\mathrm{C}$ focussed on staff knowledge and perceptions of sustainability initiatives at the university. Section D elicited staff perceptions of the barriers and challenges that the university faced in the implementation of its sustainability strategy. Section E examined their preferences for short- and long-term initiatives to implement sustainability at the university. Interviews were conducted after the analysis of survey data to elaborate on and enhance the survey results.

The survey targeted all university employees $(n=364)$ in the business faculty at the university, comprising academics (full-time), sessional teaching staff and professional staff. The survey was delivered via an email that asked staff to complete the on-line survey on 'SurveyMonkey'. Two follow-up emails were sent. 12 employees were excluded because their email addresses were not valid, leaving 352 delivered surveys.

The total number of responses was 111, consisting of 12 partial responses and 99 completed responses. Of the 12 partial responses, two were excluded from the analysis because only a small proportion of the questions had been completed. Of the remaining ten 
partial responses, three completed $53 \%$ of the questions, two finished $63 \%$ of the questions and five completed $90 \%$ of the questions. These ten partial responses were included in the analysis. The 109 usable surveys represent a response rate of $31 \%$ from the 352 delivered surveys.

To further explore some of the issues raised by the survey responses, we conducted one semi-structured interview of a key employee in the university's Sustainability Office ${ }^{4}$ (Interviewee 6) and five semi-structured interviews with key management personnel in the business faculty who had responsibilities for staffing and/or resources at an executive level. The view of a key employee in the university's Sustainability Office allows for insights into the content of the archival materials used in the study and an opinion from the university's top management on the challenges of implementing the sustainability strategy during its early phase. The interviews with key management personnel in the business faculty provide a diversity of perceptions on the phenomenon under investigation. Whilst the interview respondents held key management positions in the business faculty, each also had at least one other position: academic staff, professional staff, sessional staff and member of the university SWG. Interviewee 1 was an academic staff and a member of the university SWG; Interviewees 2 and 4 were both academic and professional staff; Interviewee 3 was a sessional and professional staff and Interviewee 5 occupied three positions: academic and professional staff and member of the university SWG. In their multiple capacities, the interview respondents from the business faculty were able to provide insights into the major influences operating in each group they belong to from a perspective that may not be available from an individual associated with only one of the groups (Selltiz et al., 1976). Those interviews were recorded and transcribed and are used to inform the interpretation of the survey responses in the analysis below. Because the survey responses were anonymous, some or all of the five business faculty interviewees may have also completed the survey. 
Interpretations of the survey responses are also offered from a perspective of the authors being members of staff and students at the university.

\subsection{Demographic information}

Demographic information obtained from Part A of the survey responses for professional, sessional and academic staff is provided in Table $1 .{ }^{5}$ Panel A indicates that responding professional staff, who are all full-time employees, are relatively senior, with two-thirds positioned in middle management and some representation from senior management in the university as well. The profile of the academics shown in Panel B is also spread across middle and senior levels, with almost half of responding academics holding lecturer positions, and about one third at professorial levels.

< Insert Table 1 here >

\section{Analysis of results}

The analysis focuses on the views of staff in the business faculty on the university's sustainability strategy in the early phase of its implementation. Selected responses from Parts B to E of the survey are presented in Table 2 and discussed in the following subsections. When available, the views of the key employee in the Sustainability Office and top management of the business faculty are provided in the discussion.

\section{$<$ Insert Table 2 here >}

\subsection{Understanding of sustainability}

While the majority of respondents indicated that they are either Familiar or Very familiar with the term 'sustainability' (Table 2, Row 1), the proportions of each staff group providing this response varied significantly. Professional staff were more than twice as 
likely to give these responses as sessional staff. This indicates that familiarity with the term ‘sustainability’ was not uniform across staff groups.

Majority of staff's understanding of sustainability was in relation to the natural environment. Staff generally thought of sustainability as 'Protecting natural resources/environment' (Table 2, Row 2). The next most common views involved personal actions: 'Recycling/conservation/preserving' and 'Reducing greenhouse gas emissions'. These rankings are consistent across the three groups of employees. The high level of awareness of sustainability across the faculty staff could be attributable to the university's sustainability strategy and climate initiatives by the federal and state government, which were introduced in the three years before the study. Indeed the level of awareness and understanding of sustainability as relating to the environment appear to have been developed outside of any formal university induction given that a high proportion of the respondents stated that they did not have any sustainability related education or training (Table 2, Row 3). All five interviewees from the business faculty also thought that the university's strategy on sustainability was focused on the environment:

The main game is sustainable operations. So things like energy efficiency, water efficiency, waste management, looking at the transport footprint of people that are visiting campus (Interviewee 1).

In the faculty itself, sustainability is focused around things like saving paper (Interviewee 4).

Staff's conception of sustainability as relating to the natural environment was in line with the university's focus at that time, which meant that the university's intended holistic approach to sustainability was yet to be fully implemented:

There was a bigger focus on operations, so water, energy, waste, transport procurement, those kinds of operational aspects and that comes out in the strategy quite clearly. The attention to learning and teaching, research and community 
engagement, which are really the core aspects of the university don't get as much attention (Interviewee 6).

However, it is doubtful that a university strategy on sustainability that focussed on the environment was acceptable and satisfactory to business academics who participate in the administration of their collective affairs:

There's the issue of the demographic profile of the staff and the sustainability of the academic cohort and that's an issue that's very big for management. We've got an ageing staff profile ... (Interviewee 4).

I don't think we have probably thought too much about all other dimensions of sustainability which relate to ethical sustainability and some of the issues around sourcing and resourcing of supply, all the other kinds of dimensions of it (Interviewee 2).

There seems to be a suggestion in Interviewee 2 and 4's comments that the university's sustainability strategy also must embrace the social and economic elements of sustainable development, in addition to the environmental (see Godemann et al., 2014). Curiously the view expressed by Interviewee 2 is not in accord with an actioned item of the SWG in March 2009, which indicated that "the only options now available to staff are either sustainable forestry paper or $100 \%$ recycled paper" (SWG, 2009a). As discussed below this could be attributed to poor communication channels from the University to the business faculty.

In contrast to the high proportion of staff who were aware of sustainability as an issue for society, a lower proportion of respondents were fully aware of the university's sustainability initiatives. A majority of respondents were aware that the university has set sustainability as one of its visions (Table 2, Row 4), but only one in four respondents were aware that the university had set sustainability targets (Table 2, Row 5). Notably a relatively high proportion of professional staff were aware of the sustainability targets compared to the 
overwhelming majority of sessional staff who were not aware. More than half of respondents were also not aware of the university's Sustainability Office, which is primarily responsible for sustainability projects (Table 2, Row 7). A similar reaction was obtained in regard to the SWG:

It's a bit of a mysterious group. It may be that they are doing really good work and that are really effective at departmental level ... I kind of wonder what on earth they are doing (Interviewee 2).

However, the key employee of the university's Sustainability Office recognised the lack of awareness of the university's employees:

It just wasn't front and foremost in people's minds, so I really had to start getting them aware that we even existed, because most people didn't know (Interviewee 6).

This lack of knowledge of university sustainability initiatives was at least twice as prevalent among the sessional staff, compared to professional staff and academics (Table 2, Rows 4, 5 and 7). An explanation that could support the overall lack of awareness of university sustainability initiatives and the differential levels of awareness of sessional, academic and professional staff is the university's communication of its sustainability goals and policies (Table 2, Row 6). Majority of staff noted that effective communication was Limited, with sessional staff indicating a stronger perception of ineffective communication on sustainability compared to academic and professional staff.

Overall, our survey results indicate that there may be difference between staff's levels of awareness of the concept of sustainability and of the university's sustainability initiatives. We explore the implications of these findings using Piderit's (2000) dimensions of cognition and intention, noting once again that the dimension of emotion is not included in this study. We now turn to those survey responses to identify whether the lack of 
awareness of university sustainability initiatives is a source of ambivalence for staff in supporting the university' sustainability strategy.

\subsection{Cognitive reactions to sustainability}

Survey respondents indicated a high level of agreement with the importance of sustainability in general, which accords with their high level of awareness of the issue of sustainability. A clear majority of respondents either Agreed or Strongly agreed with the statement 'We should always strive to protect and conserve the environment for present and future generations' and Disagreed or Strongly disagreed with both statements that 'It's only worth doing environmentally friendly things if it saves money' and 'The effects of climate change are too far in the future to worry about' (Table 2, Rows 8, 9 and 10). Consistent with their views on sustainability in general, a clear majority of faculty staff also indicated support for the university's adoption of sustainability as one of its strategies (Table 2, Row 11).

However, in what might seem an aligned statement, 'that there are sustainability issues currently facing the university' a majority of respondents indicated their agreement, and one third of respondents had "not decided" in response to this question (Table 2, Row 12). When we analysed the responses to this question by type of staff, we found a statistically significant difference between the responses of the three groups. The difference between rates of belief in university sustainability problems and support for university policies does not derive from the views of professional and academic staff, for whom the rate of belief in sustainability issues at the university was almost identical to the rate of support for university policies. The difference between the responses to the two questions comes from sessional staff, for whom the rate of belief in sustainability as an issue for the university was much lower than their willingness to support university policy. In other words, sessional staff expressed support for the strategy without a high level of awareness of 
a problem. Overall, the cognitive reactions of staff at the business faculty reflect a strong positive belief in the university's pursuit of a sustainability strategy. This positive belief is consistent with their own personal beliefs of the importance of sustainability in general.

When the respondents were asked to provide their perceptions of the three main reasons that the university adopted sustainability as its strategy, the top three reasons were: 'to maintain the University's image and reputation', 'to protect its environment' and 'to recognize the impact of its activities on the environment'(Table 2, Row 14). On these reasons, interviewees elaborated that:

Sustainability is one of those issues that organisations which are looking to promote themselves as being modern and leading edge tend to adopt (Interviewee 1).

To keep pace with other universities, keeping up with the Joneses so to speak. Other universities are doing it, so must we (Interviewee 5).

What drives it is economics (Interviewee 3).

These findings are consistent with those found in studies of universities where reputation management (Sammalisto and Arvidsson, 2005) and pressure from peer institutions (Ferrer-Balas et al., 2008) were identified as driving forces in the continuing interest in sustainability. Separating individual respondents by whether or not they believe that sustainability is an issue for the university makes the tension within their own views quite apparent. We analysed individual responses. We found that for the group of 67 respondents who believed that sustainability is an issue, the majority opinion of the main reason that the university has adopted its strategy was to maintain its image and reputation. In contrast, the main reason of protecting the environment was the majority opinion for those 42 respondents who are not sure, or do not believe, that sustainability is an issue for the university. With the former respondents, there seems to be a sense of urgency for sustainability to be addressed given identified environmental issues. 
It is illuminating to note that some staff in the business faculty 'sensed' correctly that for the Sustainability Office of the university, the adoption of a sustainability strategy was driven by an imperative to maintain a reputation and to keep up with the Joneses so to speak':

..this was at the time when the movement was becoming quite strong and in general, the audience being the general community was just really gaining momentum about climate change, so it was still a positive message through media. It was still getting a lot of air time and a lot of other organisations were starting to build their reputation on it. ... it was a reputational risk (Interviewee 6).

The business imperative was also 'sensed' by some staff in the business faculty as paramount for the university:

There were financial gains to be made in looking at our energy and our water and our waste and our actions in those areas, because you're talking about resource efficiency, which is also a financial efficiency, so yeah, it was a straightforward business case (Interviewee 6).

The Vice-Chancellor at that time articulated why he was backing the sustainability strategy, which also echoed the sentiments of staff in the business faculty:

Firstly, it is good business; secondly it is good for the environment; and thirdly and most importantly, it is part of our education, teaching and research focus (SWG, 2009b).

In analyzing staff's assessment of the likelihood of the introduction of a sustainability strategy leading to organizational benefits, it is striking that they reflect both the intentions of the university's top management and the anticipated benefits of reputation and financial gains to the university. Tellingly, irrespective of the university's rationale for its sustainability strategy, sampled staff at the business faculty were in unison in the positive belief in the university's strategy. 
The Vice-Chancellor's pronouncement that sustainability was part of the university's education, teaching and research is an odd one, however, because the SWG was, in 2009, still producing resources for academic staff by employing writers from all the faculties for input into the meaning of sustainability in the curriculum (SWG, 2009c). This initiative was "to help academics conceptualise sustainability in the curriculum" (SWG, 2009c, p.2). A 'Sustainability in the Curriculum' workshop was held in September that year where all the heads of departments were invited to open discussion about issues of sustainability in the curriculum (SWG, 2009d). Based on these accounts of events in 2009, it seems that the Vice-Chancellor was divorced from the most likely scenario that sustainability was not yet part of the university's teaching and research.

We examine the respondents' own views on the university's sustainability performance. About one third of respondents believed that the university's performance on sustainability had been Average, with a further one third of respondents indicating that they Don't know (Table 2, Row 15). This high level of non-committal response to a question of performance could be indicative of poor communication of the university's initiatives and performance particularly among sessional staff who comprised half of the Don't know respondents. It is consistent with earlier reported finding of lack of awareness of the university's sustainability initiatives.

Finally, when staff were asked whether or not they agree with statements about the university and sustainability, their responses support our previously reported findings about the differences between the groups. Professional staff as a group are more likely to agree with such statements, and academic staff are the least likely to agree. In answer to 'Improving university sustainability is important' (Table 2, Row 16), Agree or Strongly agree was the response of all professional staff, and clear majorities of sessionals and academics. In answer to 'Adopting a sustainability strategy can improve the university's 
image and enhance its reputation' (Table 2, Row 17), Agree or Strongly agree was the response of almost all professional staff and sessionals, and a majority of academics. In regard to the statement, 'The university should only implement sustainability initiatives that produce cost savings' (Table 2, Row 18), Disagree or Strongly disagree was the response of majorities for each group. Curiously, the professionals who were closest to matters of budgeting and expenditure, did not have the highest level of agreement with the statement 'Creating a more sustainable university can lead to long-run cost-savings for the university' (Table 2, Row 19).

We have evaluated the cognitive reactions of the three groups of staff at the university, based on their responses to a set of questions that probed their beliefs and attitudes regarding sustainability in general, and sustainability at the university. We juxtaposed their verbal support for university policy and their personal beliefs. Whilst their beliefs that sustainability was an important cause were reflected in their support of the university's sustainability strategy, there are indications that they were generally not aware of the university's plans and ability to implement the strategy. Most staff were not aware of the university's sustainability initiatives and could not provide a view on the university's sustainability performance. In addition, findings suggest that staff generally believed that protecting the environment was a worthy cause for the university to pursue regardless of whether sustainability initiatives would result in cost savings. That respondents thought that the university was prompted by financial gains appears not to be in accord with their personal beliefs of sustainability as a worthy cause unencumbered by financial considerations. Reflecting the complex environment in which universities now operate, where economic pressures and organizational logics work against the tradition of collegiality as an organizational norm (Godemann et al., 2014, p.220), an alternative explanation is proposed. Staff seem to acknowledge that there could be financial gains for 
the university in pursuing efficient use of resources and that indeed this could be a reason why the university adopted its sustainability strategy. However, given the high level of government and community awareness of and support for sustainability, there was also a reputational risk that the university faced if it did not adopt a sustainability strategy (as stated by the key personnel of the University Sustainability Office). On the other hand, positive reputational benefits could accrue to the university in adopting a sustainability strategy.

The following section analyses their responses to questions about their intentions to act, to determine whether staff translate their personal beliefs into deeds, and to identify additional sources of ambivalence and resistance.

\subsection{Intentional reactions to sustainability}

Considering sustainability generally, a very high proportion of respondents Agreed and Strongly agreed with the statement that 'The community and government should work together to resolve environmental issues' (Table 2, Row 20), with a lower proportion who Agreed and Strongly agreed with the statement that 'The Australian government should impose regulation to reduce carbon emissions immediately' (Table 2, Row 21), indicating support for governmental sustainability actions in general and a preference for co-operative initiatives and solutions to sustainability issues.

However, this abstract preference was not evident when asked about their own participation in environmental initiatives at the university. In stark contrast to the expressed recognition and support for sustainability issues and initiatives at the university, only one quarter of respondents indicated that they were willing to participate in the university's sustainability initiatives as volunteers (Table 2, Row 22), with a similar proportion clearly not willing to participate and almost half of the respondents undecided. For those who were willing to act on such initiatives, the following top three reasons were given: 'Sustainability 
initiatives require collective action', 'Personal contribution is important' and 'Sustainability is important for the university' (Table 2, Row 23). The most common reason for nonparticipation in such initiatives was the lack of time. Almost half of the survey respondents were non-committal on this question.

The above responses indicate dissonance between cognition and intention. Whilst staff in general, expressed a view that sustainability as a strategy is worth pursuing by the university, they were not willing to act to fully support the implementation of this strategy. However, it may be that staff were already involved in sustainability activities on campus, and did not have time for any additional activities? This does not seem to be the case, judging from their responses to the question of how they contributed to the university's sustainability strategy. Most responses were simple and relatively less visible tasks such as 'Recycle paper', 'Turn off computer at the end of each day' and 'Turn off the lights at end of each day' (Table 2, Row 24).

Most people are good anyway, they go out at night, they turn their computers off, turn their lights off, or the last one out at night, they turn the lights off (Interviewee $5)$.

Everybody has a role ... I wonder without the information to support that it's very difficult, I think, to make a case to people to say look we should do this and look, look at the difference it's making (Interviewee 1).

The comment by Interviewee 1 could also explain why more demanding and publicly visible options such as 'Use public transport', 'Participate in volunteer activities' and 'Car pooling' were rated lowest by respondents (Table 2, Row 24). The use of measurement to demonstrate a positive impact on sustainability is also identified by Interviewee 1. Another explanation gains plausibility through the expressed view by staff that resolving environmental issues require collective effort. Whilst staff supported the 
university's sustainability strategy, staff had a low level of awareness of university sustainability targets, which majority of staff attributed to limited communication by the university. Admittedly staff were contributing to the sustainability cause in their individual, less visible and unaccounted work tasks but they were yet (at the time of the survey) to match their high level of awareness of sustainability and support for the university's sustainability strategy with collective actions in the workplace. We sense positive energy in this tension as potential for future collective action.

When asked whether it is hard to change habits to be more environmentally friendly (Table 2, Row 25), respondents were evenly split between agreement and disagreement. It is the academics who are more likely to agree that change is difficult. These differences are statistically significant, and could be viewed as academics' conservative approach to change (Levin and Greenwood, 2001), which was confirmed by an interviewee:

I think it is important to understand that sustainability is about little steps. What can you do in your life to make things more sustainable? To think twice before you print something out. That doesn't mean that you don't do it, but you weigh up the pros and cons. So a greater sensitivity, a greater awareness ... (Interviewee 4).

The key employee in the university's Sustainability Office seemed to be in accord with this sentiment:

If we can get them to think about their practices, that's a step forward in engagement and awareness ... so that's when we got the Turn Off, Turn Green campaign going. .. it was about them becoming aware and them thinking about their practices within their own little environment (Interviewee 6).

As Interviewee 1 previously noted, most respondents Agreed and Strongly agreed with the view 'It is important to measure and report on sustainability' (Table 2, Row 26). Notably despite the University releasing its sustainability report earlier in the year, Interviewee 5 questioned: 
What are we actually measuring? What do we want to measure? What's important? ... Maybe they collect many tonnes of garbage we use every day, but how did they report that? How does it get collated into some type of formal reporting mechanism?

Interviewee 4 also expressed concern that:

... it ends up being for its own sake. This becomes an end in itself and a marketing and a branding exercise which has dollar values; it's a business case. We end up focusing on extrinsic value rather than the intrinsic value of doing sustainability.

The comment by Interviewee 4 also supports the general view of the survey respondents that a sustainability strategy should be implemented irrespective of the business imperative.

Prior research identified lack of interest, commitment and participation by stakeholder groups as a barrier to the integration of sustainability into higher education (Evangelinos et al., 2009; Tilbury et al., 2005; Velazquez et al., 2005). We find evidence of such a barrier within the faculty at the university we have surveyed, in different manifestations for different staff groups (Table 2, Row 27). For academics, the lack of commitment and participation is not due to lack of belief in sustainability in general, but lack of engagement with the way that the university has introduced its policies: many of them gave non-committal answers to specific questions about sustainability at the university. On the other hand, professional staff were willing to support the university's sustainability strategy, but do not seem willing to go beyond what was required. Sessionals were also generally willing to participate, but had insufficient communication from the university to know what they should do. However, it seems that staff had also identified ways to overcome this barrier:

We should be setting targets on things like the amount of garbage we collect and all that sort of thing. Establish some simple metrics. Then we could say for example, we enrolled 15 per cent more students but our total waste was only two per cent more (Interviewee 3). 
However prior and protracted attempts to embed sustainability at the business faculty had proved unsuccessful:

We put sustainability on to the agenda ... the deal I made was that every week the sustainability office will provide to us an issue or a topic to discuss like paper consumption or travel or power consumption inside the building or technology or something. We received no information from the sustainability office. I left it on the agenda for 12 months and I took it off (Interviewee 2).

\subsection{Identified barriers and suggested strategies}

The above diagnosis of the potential barriers to the integration of sustainability into the university's culture is based on analytical interpretation of aggregate responses to various questions by the staff using Piderit's (2000) dimensions of cognition and intention of ambivalence. We also asked staff directly to identify what they consider to be the main barriers to the successful implementation of a sustainability strategy by the university. These are summarised in Table 3. Some of their individual interpretations reflect on the university as a whole, and others reflect on their own situations. The barrier that is most commonly identified by staff overall is 'Lack of interest among members of the university', and this is also the most identified barrier by academic staff, and the second most commonly identified barrier by sessional staff.

It's actually a lot easier to engage with professional staff than academic staff with this sort of issue because the professional staff are perhaps closer to the operational aspect and so they can identify more readily with some of the issues. Whereas for academic staff they tend to be more focused on delivering their teaching and research outcomes (Interviewee 1).

Indeed engaging with academic staff was recognised as difficult by the key employee in the Sustainability Office:

I didn't really know what I wanted from academic staff. I knew I wanted them to think about how sustainability could fit within what they were teaching or whether it 
did fit within what they were teaching, but I really didn't know how to articulate it. (Interviewee 6).

A related barrier is the third one overall, 'Results too far into the future', which was also the most identified barrier by sessional staff and the second most identified by professional staff. This staff-identified barrier aligns with our analysis of their responses to the survey as a whole, that ambivalence and hence a lack of engagement among staff is potentially widespread and could be a fundamental problem to be overcome.

\section{$<$ Insert Table 3 here >}

The next most commonly identified barriers also accord with the findings of this study, that of 'Profit orientation by the university' and 'Conflicting goals with the university'. "Profit orientation' is the most identified barrier by professional staff, and the fourth most identified by academics and by sessionals. 'Conflicting goals' is the second most identified goal by professionals and by academics. Worth noting is that both professional and academic staff groups strongly identified it as a barrier.

The other strong barrier that is expressed by staff in their answers to this question is the lack of integration of sustainability into the culture of the university, into its reports, its financial records and importantly, its research. The third most identified barrier overall is 'Lack of data/information', and this is echoed in the concerns of professional staff: 'Lack of knowledge', 'Communication problems' (their second most identified barriers), those of academics: 'Lack of data', 'Lack of research evidence' (their second and fourth most identified barriers), and those of sessionals: 'Lack of data', 'Lack of knowledge' (their second and fifth barriers). These responses affirm earlier discussions on the lack of awareness of university accountability and performance on sustainability. 
Finally, we asked staff to give their opinions on various sustainability initiatives that the university should adopt in the short-term and in the long-term. This was their opportunity to identify the strategies that could overcome the concerns that they had about sustainability at the university. As articulated by Waddell and Sohal (1998, p.545), resistance could encourage the search for alternative methods to resolve the conflicting views on the proposed change. It could be the catalyst for innovation.

\section{$<$ Insert Table 4 here >}

In the short-term, the primary focus of staff was on operational actions that would affect the university's consumption of natural resources. For staff overall, as well as professional and sessional staff, the most important initiative was 'Recycle all recyclable waste'. For academics this was the second most important initiative. Other top initiatives that focus on consumption of natural resources were the fourth one overall: 'Promote more use of public transport', and the fifth: 'Reduce water usage and improve university water conservation'. Professional staff also considered 'Encourage and reward participation in sustainability actions and initiatives' to be quite important, ranking it third.

Two other themes emerge from the short-term initiatives: the need for better communication at the university, and the need for sustainability to impact the research and learning and teaching agendas of the university community (see Table 4, Panel A). 'Utilise various media and methods of communication regarding sustainability' was the second most important initiative overall, a ranking that was fairly uniform across all staff groups (second for professionals and sessionals, and third for academics). Alongside this basic plea for more information on the issue of sustainability, comes the reminder that universities' raison d'etre is scholarship. Without sustainability impacting the research that is conducted, or the learning and teaching programs, it will remain an operational matter, and not fully part of the university culture. Academics also identified 'Encourage and support sustainability 
research by providing more research grants' as the most important short-term initiative, and sessionals also rated it as important (ranking it third). More surprising is that 'Stimulate academic debate about sustainability, its meaning, values and approaches to learning and teaching' was not rated in the top five most important short-term initiatives by either group who deliver these services, but instead it was ranked fifth by professional staff.

The emphasis put by academic staff on funding sustainability research instead of learning and teaching as a short-term initiative seems curious. Academics typically resent institutional intrusions into both teaching and research (Dearlove, 1998; Gudz, 2004; Mcintosh et al., 2001). Perhaps the response from academics in this study is conditioned by the environment in which Australian universities operate with business faculties, in particular, adept at commodifying education to successfully generate revenues for universities (Parker and Guthrie, 2010). Was the response a challenge to the university to redeploy resources to business research, which is another core function of the university? Was the low emphasis on learning and teaching reflecting the institutionalized approach to commodifying business education in Australia? It seems that Australian business academics share decisions relating to teaching with universities' management. Moreover, the university examined in this study was undergoing a period of significant upheaval with far-reaching changes in the curriculum already in train. Coincidentally an initiative on sustainability in teaching was operational with representatives from all the faculties producing resources to help academics conceptualise sustainability in the curriculum (SWG, 2009c, p.2).

In the long-term assessments of sustainability initiatives (see Table 4, Panel B), funding of sustainability research was ranked as the most important initiative by all staff overall, and by academics and sessionals as separate groups. This highlights that staff appreciated the importance of sustainability impacting on a university's key activity of research and not just its supporting activities. Including sustainability into learning and 
teaching is not ranked as highly, being the fifth most important initiative overall, with a ranking of third by professionals and fourth by academics.

In my discipline, you would think that we teach sustainable marketing or green marketing or social marketing which we do, but that's not a response for the university to say you need to teach it. It's a natural response and a discipline to what's happening in the world, the same in accounting (Interviewee 2).

The insight from Interviewee 2 speaks to academic autonomy, specifically to research-led teaching. In this study, university management provides the vision and the structure for curricula development, whilst academics decide on the content of courses. There seems to be an insistence on discipline-based research evidence to support the inclusion of sustainability in teaching courses.

Initiatives related to the consumption of natural resources, such as recycling of waste and reducing greenhouse gas emissions, ranked highly in the long-term as well as the shortterm. 'Recycle all recyclable waste' was the second most important long-term initiative for all staff, and was also second for academics and sessionals, and third for professionals. 'Reduce air pollution, and in particular greenhouse gas emissions' was not mentioned as an important short-term initiative by any group of staff, but emerged as the third most important long-term initiative overall, and was second ranked by academics. This result recognised that such a change is a long-term goal.

A third theme emerging in the long-term important initiatives identified by staff was the need to measure, record and report on sustainability matters. Sustainability issues will only be taken seriously by decision-makers across the university, regardless of their personal beliefs on the matter, if they are included in the accountability systems. This view is expressed by staff who ranked 'Incorporate sustainability measures into internal financial reports' as the third equally most important initiative overall. It was seen by professional 
staff as the most important long-term strategy, alongside 'Comprehensively account for the cost of its carbon footprint'. Interestingly, this need was not reflected in the responses of academics, but was reflected by the sessionals, who ranked 'Produce an annual sustainability report' and 'Incorporate sustainability measures into internal financial reports' as the third and fourth most important initiatives. In the short-term, staff saw communication about sustainability as an important initiative, but in the long-term, communication appears to have been replaced by the need to embed sustainability into the university's accountability systems:

What we need to do along with the accountability we have to start assigning responsibility. I think one of the things we need to do is start making in all its forms a KPI (key performance indicator). You could make it for every individual. Just a simple thing in your annual PDR (performance development review) tell us - give us an example of something you did this year to advance the university's sustainability vision (Interviewee 3 ).

... if you said to me we are going to put a KPI in your work plan that says you will reduce the number of sheets of paper that you consume. Great, I can do something about that (Interviewee 2).

\section{Conclusion}

A dominant perspective of employee resistance is that it is an oppositional and a negative reaction by employees to change proposals that alter the status quo (e.g. Zaltman and Duncan, 1977); it is irrational and dysfunctional (Ansoff, 1988). In this study, the authors took a view that resistance does not have to be oppositional and a negative reaction. Instead, we aligned with an energising position that employee resistance could be linked to organizational adaptation and learning. This view is adopted because "it is possible for change recipients to be internally positive toward a change whilst simultaneously taking actions or delivering communications that change agents call resistance" (Ford et al., 2008, 
p. 371). Applying Piderit's (2000) dimensions of cognition and intention of ambivalence, a change recipient might have a strong positive belief about a proposed change but have a negative intention to not support it. Here there is dissonance between cognition and intention or what change agents will call resistance. Likewise ambivalence could occur along the dimension of cognition. An employee can believe that a proposed change is both necessary for the organisation's survival in the industry but also believe that the change is not yet sufficiently planned. In this study, Piderit's notion of ambivalence was used to closely examine survey responses of staff in a business faculty at an Australian university to the issues of sustainability in general and the university's sustainability strategy and initiatives. In particular, the cognitive and intention dimensions of ambivalence were mobilized to identify staff's beliefs and intentions to act on sustainability. It was identified that a high, positive level of belief that a sustainability strategy was worthwhile for the university to pursue was not (yet) matched by a high, positive level of intention to act to support university sustainability initiatives.

Deploying the dominant view of employee resistance would have considered the lack of collective action by staff from the business faculty as oppositional and negative, potentially introducing delays, costs and instabilities into the process of strategic change. This characterization could have overlooked the high, positive level of belief in the university's sustainability strategy and staff's individual, work-related yet unaccounted contributions to implement (or at least take actions consistent with) the university's sustainability strategy. Indeed, the lack of support for sustainability initiatives requiring collective action could be construed as 'resistance' but one that we suggest, is nonoppositional. Instead it reflects ambivalence at that time, a dissonance between the strong positive belief in the university's sustainability strategy and the weak intention to take collective action. This is markedly pertinent given the sampled staff's belief that 
sustainability strategies require collective action. In making sense of the dissonance in the belief in collective action for sustainability and the intention to take collective action, surveyed and interviewed staff offer ways, perhaps unintentionally, that would enable them to collectively act. Importantly they affirmed the university's current focus on initiatives relating to the environment. If indeed, the university has a holistic approach to its sustainability strategy, they propose that the economic and social elements of a holistic approach to sustainability be also considered and at an operational level that resources be earmarked for research grants on sustainability, better communication and better measurement and accountability mechanisms.

There is a sense, if we may suggest, of an enabling form of resistance whereby staff appear to embrace little steps as the way to effect change toward sustainability at the individual level. Equally, however, there is recognition that the pursuit of a holistic approach to sustainability requires centrally organized collective action and that in this university at least, staff seem to challenge the university to take the big steps first. It appears that only then will the majority of ambivalent staff at the business faculty match their strong belief in collective action for sustainability with a strong intention to collectively act. There is a sense of anticipated 'coupling' or 'connectedness' by staff at the business faculty with university's management to implement a holistic approach to sustainability.

This study also highlighted differences in staff profile, which could impact on how the university engages with its staff in regard to sustainability. Academics were most aware of sustainability targets but least impressed with the university's performance and doubtful that staff could change their behaviour. Whilst valuing academic freedom and autonomy, academics also recommended that the university provide funding for research on sustainability. Sessionals were least aware of the university's sustainability challenges and targets but supportive of the strategy yet did not see much worth in reporting on 
sustainability. Professionals, on the other hand, had the most positive view of performance and individual's propensity to change behaviour.

It is our view that top management would be wise to heed staff's ambivalence and recommendations to shape organisational change for sustainability at the university. These suggestions from staff are valuable because encouraging commitment to changes in personal behaviour and mobilising action from staff, require conversations for performance (Ford and Ford, 1995). Top management should not mistakenly assume that understanding is, or should be, sufficient to produce action (Ford et al., 2008). There should be both conversations for understanding and conversations for performance (Ashkenas and Jick, 1992; Beer et al., 1990). Through these conversations, people seek to comprehend the situation (Mintzberg et al., 1976); work to make sense of the issue, problem, or opportunity; and move the matter forward (Dutton and Ashford, 1993). Conversations for performance focus on producing the intended results. Indeed staff fed back to top management of the university that in the short-term there should be better communication on the university's sustainability initiatives (to make sense of the opportunities) but in the long-term better accountability mechanisms (to produce the intended results). Given the temporal focus of this study, however, we were unable to investigate whether the ideas fed back by staff 'energised' top management to pay attention to aspects of the strategy implementation that were not planned enough or to adjust the pace, scope or sequencing of the implementation of the change. ${ }^{6}$

This study complements prior literature that has focused on engagement by academic staff with university strategies, and that has paid little attention to the views of other key employee groups: professional staff and sessional teaching staff. Whilst this study found statistically significant differences in cognitive and intentional responses to the university's sustainability strategy amongst academic, professional and sessional staff, we note that the 
significant results may be attributed to random influences rather than those that we have elucidated. The differences in the nature of work and employment of university staff and their impact on staff cognitive and intentional responses to university's sustainability strategy and initiatives could be further explored and developed in future research using indepth interviews and focus groups. We have surveyed staff at one type of faculty at one Australian university. In so concentrating and narrowing our attention we have gained an insight, but perhaps lost generalizability for our findings. As researchers, employees and students of the university examined in this study, we were initially challenged to distance ourselves and interpret the survey and interview data as 'objectively' as possible. This was difficult to do. Instead, we opted to acknowledge that just like the interviewees; our multiple capacities in relation to this study allowed us to provide additional insights that may not be available from a researcher who was not an employee and a student of the university (see Selltiz et al., 1976). The insights we offer are subjective and we alert the readers to this. They may not necessarily apply to another empirical setting. We encourage future researchers to further investigate the attitudes of these three staff groups in other types of faculties at other universities, and to apply Piderit's notion of ambivalence and its dimensions of cognition, intention and emotion as they have the potential to help understand the sources of resistance by staff to the introduction of a sustainability strategy and indeed to organisational change at higher educational institutions. 


\section{Notes}

1. Composed in 1990, the Tailloires Declaration is a ten-point action plan for incorporating sustainability and environmental literacy in teaching, research, operations and outreach at colleges and universities. It has been signed by more than 350 universities in over 40 countries. In Australia, 21 universities are signatories, although the university studied in this paper is not on the list (www.ulsf.org/programs_tailloires_signatories.html\#Australia, 14 ${ }^{\text {th }}$ June 2013).

2. Ford et al. (2008) used the term change recipients to represent those people who are responsible for implementing, adopting or adapting to the change (s). Change agents, on the other hand, refer to those who are responsible for identifying the need for change, creating a vision and specifying the desired outcome and then making it happen. Ford et al. (2008) adapted these definitions from Kanter et al. (1992).

3. Ethics approval from the university was obtained for the survey and the interviews. The survey instrument is available from the corresponding author on request.

4. We thank the anonymous reviewers for this suggestion. The key employee has specific knowledge of the history and evolution of the university's sustainability strategy and has been an employee of the university's Sustainability Office since its inception. It is acknowledged that frailty of the human mind is a major consideration as the interviewee was being asked to reflect on the past. To partly address this challenge, photo-elicitation was used to potentially draw out the conscious and subconscious recollections of the interviewee (Heisley and Levy, 1991; Parker, 2006). Photo-elicitation involved providing the interviewee with copies of the university's sustainability strategy and sustainability report for 2009 prior to the interview.

5. The distribution of staff across academic, sessional-academic and professional staff for the University was at 37:10:53 in 2009 as per the annual report. The corresponding distribution for survey respondents was 43:40:17. It is noted that the survey response rate from all categories of staff is not reflective of the University distribution. The implications of the response rate to the analysis of findings are further developed in the questionnaire commentary.

6. Results of the survey were provided to the Sustainability Office in 2009. 


\section{References}

Adams, D. (1998), "Examining the fabric of academic life: An analysis of three decades of research on the perceptions of Australian academics about their roles", Higher Education, Vol. 36, pp. 421-435.

Albrecht, P., Burandt, S. and Schaltegger, S. (2007), "Do sustainability projects stimulate organizational learning in universities?", International Journal of Sustainability in Higher Education, Vol. 8 No. 4, pp. 403-415.

Amason, A. C. (1996). "Distinguishing the effects of functional and dysfunctional conflict on strategic decision making: Resolving a paradox for top management teams", Academy of Management Journal, Vol. 39, pp.123-148.

Ansoff, I. (1988), The New Corporate Strategy, John Wiley \& Sons, New York, NY.

Ashford, S.J., Rothbard, N.P., Piderit, S.K. and Dutton, J.E. (1998), "Out on a limb: The role of context and impression management in selling gender-equity issues", Administrative Science Quarterly, Vol. 43, pp. 23-57.

Ashkenas, R. and Jick, T. (1992), "From dialogue to action in GE work-out: Developmental learning in a change process", Research in Organizational Change and Development, Vol. 6, pp. 267-287.

Bagozzi, R.P. (1992), "The self-regulation of attitudes, intentions, and behavior", Social Psychology Quarterly, Vol. 55, pp. 78-204.

Bassett, P. and Marshall, H. (1998), "Women Working as Casual Academics: A Marginalised Group", Journal of the Australian and New Zealand Academy of Management, Vol. 4 No.2, pp.10-17.

Becher, T. and Kogan, M. (1992), Process and Structure in Higher Education, Routledge, London.

Bebbington, J, Larrinaga-González, C. and Moneva, J. (2008), "Corporate social responsibility reporting and reputation risk management", Accounting, Auditing \& Accountability Journal, Vol. 21 No. 3, pp.337-361.

Beer, M., Eisenstat, R. and Spector, B. (1990), "Why change programs don't produce change", Harvard Business Review, Vol. 7 No. 6, pp.158-166.

Bekessy, S.A., Samson, K. and Clarkson, R.E. (2007), "The failure of non-binding declarations to achieve university sustainability: A need for accountability", International Journal of Sustainability in Higher Education, Vol. 8 No. 3, pp. 301316.

Brehm, J. W. (1966), A theory of psychological reactance. New York: Academic Press.

Brunsson, N. (1986), The irrational organization: Irrationality as a basis for organizational action and change. Chichester, UK: Wiley.

Clugston, R.M. and Calder, W. (1999), "Critical Dimensions of Sustainability in Higher Education", in W.L.Filho (ed.), Sustainability and University Life. Peter Lang, New York, pp. 31-46.

Cooper, B. and Muth, R. (1993), "Internal and external barriers to change in departments of educational administration", in T. A. Mulkeen e/ crl. (Eds.). Democratic Leadership. Norwood, NJ: Ablex Publishing Corporation. 
Conway, M. (2000), "What's in a Name? Issues for ATEM and Administrators", Journal of Higher Education Policy and Management, Vol. 22 No. 2, pp. 199-201.

Cortese, A.D. (2003), "The Critical Role of Higher Education in Creating a Sustainable Future", Planning for Higher Education, Vol. March-May, pp. 15-22.

Dearlove, J. (1998), "The deadly dull issue of university "administration"? good governance, managerialism and organising academic work", Higher Education Policy, Vol. 11 No. 1, pp. 59-79.

Dent, E. and Goldberg, S. (1999), "Challenging "resistance to change"”, Journal of Applied Behavioral Science, Vol. 35, pp.25-41.

Dutton, J. and Ashford, S. (1993), "Selling issues to top management", Academy of Management Review, Vol. 18 No. 3, pp. 397-428.

Eagly, A.H. and Chaiken, S. (1998), "Attitude structure and function", in D. T. Gilbert, S. T. Fiske, \& G. Lindsey (Eds.), Handbook of social psychology, Boston: McGraw-Hill, Vol. 2, pp. 269-322.

Elton, L. (1981), "Can universities change?", Studies in Higher Education, Vol. 6, pp. 23-33.

Evangelinos, I.K. and Jones, N. (2009), "An analysis of social capital and environmental management of HEIs", International Journal of Sustainability in Higher Education, Vol. 10 No. 4, pp. 334-342.

Evangelinos, I.K., Jones, N. and Panoriou, E.M. (2009), "Challenges and opportunities for sustainability in regional universities: a case study in Mytilene, Greece", Journal of Cleaner Production, Issue.17, pp.1154-1161.

Ferrer-Balas, D., Adachi, J., Banas, S., Davidson, C.I., Hoshikoshi, A., Mishra, A., Motodoa, Y., Onga, M. and Ostwald, M. (2008), "An international comparative analysis of sustainability transformation across seven universities", International Journal of Sustainability in Higher Education, Vol. 9 No. 3, pp. 295-316.

Ford, J.D. and Ford, L.W. (1995), "The role of conversations in producing intentional change in organizations", Academy of Management Review, Vol. 20, pp. 541-570.

Ford, J.D., Ford, L.W. and D'Amelio, A. (2008), "Resistance to change: the rest of the story", Academy of Management Review, Vol. 33 No. 2, pp. 362-377.

Gioia, D.A., Thomas, J.B., Clark, S.M. and Chittipeddi, K. (1994), "Symbolism and strategic change in academia: The dynamics of sensemaking and influence", Organization Science, Vol. 5, pp.363-383.

Glynn, M.A., Lant, T.K. and Milliken, F.J. (1994), "Mapping Learning Processes in Organizations", Advances in Managerial Cognition and Organizational Information Processing, Vol. 5, pp. 43-93.

Greene, J.C., Caracelli, V.J. and Graham, W.F. (1989), “Toward a Conceptual Framework for Mixed-Method Evaluation Designs", Educational Evaluation and Policy Analysis, Vol. 11, pp.255.

Godemann, J., Bebbington, J., Herzig, C. and Moon, J. (2014), "Higher education and sustainable development: Exploring possibilities for organisational change", Accounting, Auditing and Accountability Journal, Vol. 27 No. 2, pp.218-233.

Gudz, N.A. (2004), "Implementing the sustainable development policy at the University of British Columbia: An analysis of the implications for organisational learning", 
International Journal of Sustainability in Higher Education, Vol. 5 No. 2, pp. 156 168.

Guthrie, J. and Neumann, R. (2007), "Economic and non-financial performance indicators in universities: the case of the Australian university system and the establishment of a performance driven university system", Public Management Review, Vol. 9 No. 2, pp. 231-52.

Halsey, A.H. (1979), "Are the British universities capable of change?", New Universities Quarterly, Vol. 33, pp. 402-416.

Heisley, D.D. and Levy, S.J. (1991), “Autodriving: A Photoelicitation Technique”, Journal of Consumer Research, Vol. 18 No. 2, pp.57-272.

Holdsworth, S. Wyborn, C. Bekessy, S. and Thomas, I. (2008), "Professional development for education for sustainability: How advanced are Australian universities?", International Journal of Sustainability in Higher Education, Vol. 9 No.2, pp.131-146.

Jermier, J.M., Knights, D. and Nord, W.R. (1994), "Resistance and power in organizations: Agency, subjectivity and the labour process". In J.M. Jermier, D. Knights, \& W.R. Nord (Eds.), Resistance and power in organizations, pp.1-24. New York: Routledge.

Judson, A. (1966), A Managers Guide to Making Changes, John Wiley \& Sons, London.

Kanter, R.M., Stein, B.A. and Jick, T.D. (1992), The challenge of organizational change: How companies experience it and leaders guide it. New York: Free Press.

Kezar, A. and Eckel, P. (2002), "Examining the institutional transformation process: the importance of sensemaking, interrelated strategies, and balance", Research in Higher Education, Vol. 43 No. 3, pp.295-328.

Kim, T.G. and Rousseau, D.M. (2006), "From novelty to routine: Employee motivational shifts across phases of organizational change". Working paper, University of Delaware, Newark.

King, N. and Anderson, N. (1995), Innovation and change in organizations. London: Routledge.

Knowles, E.S. and Linn, J.A. (2004), The importance of resistance to persuasion. In E. S. Knowles \& J. A. Linn (Eds.), Resistance and persuasion, pp.3-9. Mahwah, NJ: Lawrence Erlbaum Associates.

Levin, M. and Greenwood, D.J. (2001), "Pragmatic action research and the struggle to transform universities into learning communities", in Reason, P. and Bradbury, H. (Eds), Handbook of Action Research, Sage, Thousand Oaks, CA, pp. 103-14.

Litterer, J. (1973), "Conflict in organisation: a reexamination" in Rowe, L. and Boise, B. (Eds), Organisational \& Managerial Innovation, Goodyear, Santa Monica, CA.

McIntosh, M., Cacciola, K., Clermont, S. and Keniry, J. (2001), State of the Campus Environment: A National Report Card on Environmental Performance and Sustainability in Higher Education, National Wildlife Federation, Reston, VA, available

at: www.nwf.org/campusEcology/HTML/stateofthecampusenvironment.cfm (accessed 25 February 2012).

Miner, A.S. and Mezias, S.J. (1996), "Ugly duckling no more: Pasts and futures of organizational learning research”, Organization Science, Vol. 7 No. 1, pp. 88-99. 
Mintzberg, H., Raisinghani, H. and Theoret, A. (1976), "The structure of unstructured decision processes", Administrative Science Quarterly, Vol. 21 No. 2, pp. 246-275.

Modigliani, A. and Rochat, F. (1995), "The role of interaction sequences and the timing of resistance in shaping obedience and defiance to authority", Journal of Social Issues, Vol. 51 No. 3, pp. 107-123.

Moore, J., Pagani, F., Quayle, M., Robinson, J., Sawada, B., Spiegelman, G. and Van Wynsberghe, R. (2005), "Recreating the university from within: Collaborative reflections on the University of British Columbia's engagement with sustainability", International Journal of Sustainability in Higher Education, Vol. 6 Iss. 1, pp. 65-80.

Nagy, J. and Robb, A. (2008), " Can universities be good corporate citizens?", Critical Perspectives on Accounting, Vol 19 No. 8, pp. 1414- 1430.

Orton, J.D. and Weick, K.E. (1990), "Loosely coupled systems: a reconceptualization", Academy of Management Review, Vol. 15 No. 2, pp. 203-223.

Parker, L.D. (2002), "It's been a pleasure doing business with you: a strategic analysis and critique of university change management", Critical Perspectives on Accounting, Vol. 13 Nos. 5/6, pp. 603-19.

Parker, L.D. (2005), "Corporate Governance Crisis Downunder: Post-Enron Accounting Education and Research Inertia", European Accounting Review, Vol. 14 No. 2, pp. 383-394.

Parker, L.D. (2006), "Photo-Elicitation: An Ethno-Historial Accounting and Management Research Prospect", Interdisciplinary Perspectives on Accountancy Conference, Cardiff.

Parker, L.D. and Guthrie, J. (2010), "Business schools in an age of globalization", Accounting, Auditing \& Accountability Journal, Vol. 23 No. 1, pp. 5-13.

Piderit, S.K. (2000), "Rethinking Resistance and Recognizing Ambivalence: A Multidimensional View of Attitudes toward an Organizational Change", The Academy of Management Review, Vol. 25 No. 4, pp. 783-794.

Reid, A. and Petocz, P. (2006), "University lecturers' understanding of sustainability", Higher Education, Vol. 51, pp. 105-123.

Ryan, S., Neumann, R., Guthrie, J., Mazza, C., Quattrone, P. and Riccaboni, A. (2008), "The Case of Australian Higher Education: Performance, Markets and Government Control", European Universities in Transition: Issues, Models and Cases, Edward Elgar, London, pp. 171-87.

Sammalisto, K. and Arvidsson, K. (2005), "Environmental management in Swedish higher education: Directives, driving forces, hindrances, environmental aspects and environmental co-ordinators in Swedish universities", International Journal of Sustainability in Higher Education, Vol. 6 No. 1, pp. 18-35.

Schein, E. (1988), Organisational Psychology, 3rd ed., Prentice Hall, Englewood Cliffs, NJ.

Selltiz, C., Wrightsman, L.S. and Cook, S.W. (1976), Research Methods in Social Relations, 3rd ed., Holt, Rinehart and Winston Inc., New York.

Senge, P.M. (2000), "Die Hochschule als lernende Gemeinschaft", in Laske, S., Schyett, T., Meister-Scheytt, C. and Scharmer, C.O. (Eds), Universitat im 21. Jahrhundert: zur Interdependenz von Begriff und Organisation der Wissenschaft, Hampp, Mu"nchen, pp. 17-44. 
Sustainability Working Group (SWG). (2009a), Minutes of Meeting, 9 March 2009.

Sustainability Working Group (SWG). (2009b), Minutes of Meeting, 1 June 2009.

Sustainability Working Group (SWG). (2009c), Minutes of Meeting, 29 April 2009.

Sustainability Working Group (SWG). (2009d), Minutes of Meeting, 19 October 2009.

Tilbury, D., Keogh, A., Leighton, A. and Kent, J. (2005), A National Review of Environmental Education and its Contribution to Sustainability in Australia: Further and Higher Education, Canberra: Australian Government Department of the Environment and Heritage and Australian Research Institute in Education for Sustainability (ARIES).

Thomas, I. (2004), "Sustainability in tertiary curricula: what is stopping it happening?", International Journal of Sustainability in Higher Education, Vol. 5 Issue.1, pp.33-47.

Tomlinson, E.C., Dineen, B.R. and Lewicki, R.J. (2004), "The road to reconciliation: Antecedents of victim willingness to reconcile following a broken promise", Journal of Management, Vol. 30, pp.165-187.

UNESCO. (2002), UNESCO, viewed 1 August2009,<http://portal.unesco.org/education /en/ ev.phpURL_ID=23279\&URL_DO=DOTOPIC\&URL_SECTION=201.html >.

United Nations. (2002), World summit on sustainable development: Plan of implementation. Paper presented at the Johannesburg Earth Summit 2002, Johannesburg, 26 Aug.-4 Sept.

Velazquez, L., Munguia, N. and Sanchez, M. (2005), "Deterring sustainability in higher education institutions: An appraisal of the factors which influence sustainability in higher education institutions", International Journal of Sustainability in Higher Education, Vol. 6 No. 4, pp. 383-391.

Waddell, D. and Sohal, A. S. (1998), "Resistance: a constructive tool for change management", Management Decision, Vol. 36 No. 8, pp. 543 - 548.

Wegener, D.T., Petty, R.E., Smoak, N.D. and Fabrigar, L.R. (2004), Multiple routes to resisting attitude change. In E. S. Knowles \& J. A. Linn (Eds.), Resistance and persuasion, pp.13-38. Mahwah, NJ: Lawrence Erlbaum Associates.

Weick, K. (1976), "Educational organizations as loosely coupled systems", Administrative Journal Quarterly, Vol. 21, pp. 1-19.

Zaltman, G. and Duncan, R. (1977), Strategies for Planned Change, Wiley, Toronto. 